MEJUAJUA: Jurnal Pengabdian pada Masyarakat
https://www.jurnal.yaspenosumatera.org/index.php/mejuajua
Volume 1| Nomor 2 | Desember |2021|Hal. 31-35
e-ISSN: 2807-2634

\title{
Pengenalan Hijauan Pakan Ternak dan Pemanfaatan Hasil Samping Pertanian Terhadap Anggota Peternak Waringin Center Langkat
}

\author{
Juli Mutiara ${ }^{1)}$, Yunida Berliana ${ }^{1)}$, Razali ${ }^{1)}$, Erfan Wahyudi ${ }^{1)}$ \\ ${ }^{1}$ Fakultas Pertanian dan Peternakan, Universitas Tjut Nyak Dhien, Medan, Indonesia
}

Keywords :

Hijauan Pakan, Hasil Samping

Pertanian.

Corespondensi Author

Email: :

julimutiara88@gmail.com

History Artikel

Received: 05-12-2021

Reviewed: 07-12-2021

Revised: 08-12-2021

Accepted: 08-12-2021

Published: 20-12-2021

DOI:

10.52622/mejuajuajabdimas.v1i2.19

\begin{abstract}
Abstrak.
Waringin Center adalah salah satu tempat yang mengelola kegiatan usaha penggemukan dan pembibitan ternak domba yang berada di Stabat Kabupaten Langkat, Provinsi Sumatera Utara yang dijadikan sebagai objke pengabdian masyarakat oleh Fakultas Pertanian dan Peternakan Universitas Tjut Nyak Dhien Medan. Anggota dari Waringin Center ini banyak sebagai petanipeternak terutama ternak ruminansia kecil. Pengetahuan pemberian pakan terhadap ternak perlu dilakukan sehingga dapat eningkatkan produksi ternak yang dipelihara sehingga menambah pendapatan peternak. Pengenalan hijauan pakan ternak dan pemanfaatan hasil samping pertanian perlu dilakukan mengingat didaerah tersebut masih banyak lahan pertanian yang dapat dimanfaatkan sebagai tempat sumber pakan ternak. Pengabdian dilakukan untuk melatih dan memberi informasi jenis-jenis hijauan pakan ternak dan hasil samping pertanian yang selama ini dianggab limbah oleh masyarakat dapat dimanfaatkan sebagai pakan ternak. Pelatihan dilakukan dengan mengumpulan anggota peternak Waringin Center dan memberi presentasi kepada mereka. Hasil kegiatan pengabdian yang dilakukan bahwa peserta yang merupan anggota Waringin Center mengikuti pelatihan dengan semangat dan antusias yang tinggi sehingga mereka dapat mengenali jenis-jenis hijauan pakan yang bisa dijadikan pakan ternak dan hasil samping pertanian yang bisa dimanfaatkan untuk pakan.
\end{abstract}

This work is licensed under a Creative Commons Attribution 4.0 International License

\section{PENDAHULUAN}

Pakan dapat dipandang sebagai bahan baku yang dapat dikonsumsi oleh hewan ternak untuk memenuhi kebutuhan energi dan atau zat nutrisi dalam ransum makanannya. Konsumsi pakan terhadap ternak ruminansia sangat kompleks serta banyak faktor yang ikut mempengaruhi dan biasanya dimasukkan atau di golongkan ke dalam bidang luas seperti: sifat sifat pakan, faktor lingkugan serta factor ternak (Wodzicka- Tomaszewska, et al., 1993). Sebagian besar pakan ketersediaannya bergantung oloh tanaman pakan. Keberadaan sumberdaya tanaman pakan dipengaruhi oleh unsur lingkungan baik fisik maupun hayati yang diperlukan untuk memenuhi kebutuhan pakan. Sistem penyedian pakan di Indonesia memiliki karakteristik ketergantungan oleh sistem pertanian yang ada pada suatu wilayah. 
Pakan ternak ruminansia dapat digolongkan menjadi dua jenis yaitu hijauan dan konsentrat. Hijauan pada dasarnya memiliki kandungan serat kasarnya tinggi, sedangkan konsentrat kandungan serat kasarnya lebih rendah serta kandungan energi dan protein yang tinggi (Williamson dan Payne, 1993). Konsentrat diberikan pada domba dengan tujuan untuk menambah dan meningkatkan nutrient ransum, konsumsi ransum, dan daya cerna ransum (Mulyono, 1998). Hijauan merupakan ransum utama ternak ruminansia, yang ketersediannya selama tahun tidak selalu mudah didapat.Pada musim kemarau ketersediannya jauh dari pada mencukupi untuk kebutuhan ternak, sedangkan dimusim penghujan sangat mudah didapat dan bahkan berlebih.Untuk menyediakan kebutuhan hijauan sepanjang tahun, maka kelebihan produksi di musim penghujan seyogyanya dilakukan penyimpanan dan pengawasan (Sugeng, 2000).

HPT (Hijauan Pakan Ternak) merupakan salah satu hal yang sangat penting bagi peternakan ruminansia. Tanpa adanya ketersediaan pakan yang cukup baik, ternak yang di pelihara tidak akan berproduksi secara optimal, dikarenkan makanan yang diberikan pada ternak tidak dapat tersedia secara tetap. Hijauan adalah suatu bahan pakan utama ternak ruminansia yang bisa berupa rumput baik itu rumput lapangan, rumput unggul dan sebagian jenis leguminosa. Untuk pemberian hijauan makanan ternak dapat diberikan dengan memberikan rumput unggul seperti rumput raja, rumput gajah dll atau mencampurkan rumput lapangan dengan tanaman leguminosa seperti gamal, kaliandra, turi dan lainlain yang memiliki gizi tinggi. Hal ini sangat perlu dilakukan dikarenakan ketersediaan sangat dipengaruhi oleh musim dan semakin terbatasnya padang pengembalaan disamping itu nilai gizi yang dikandung sangat rendah.

Sumber pakan dalam meningkatkan produktivitas ternak dapat menggunakan bahan baku pakan berbasis produk samping tanaman dan industri pertanian. Pasar domestik dan ekspor yang semakin meningkat mendorong luas lahan tanaman perkebunan seperti kelapa sawit dan tebu makin meningkat. Demikian juga konsumsi beras yang terus meningkat dan program swasembada beras yang konsisten mendorong semakin meningkatnya luas panen padi. Ketiga tanaman tersebut selain menghasilkan produk utama juga menghasilkan produk samping tanaman dan industri pertanian yang berpotensi untuk pakan ternak ruminansia

Sutrisno (2002) mendefinisikan limbah sebagai sisa atau hasil ikutan dari produk utama. Limbah pertanian adalah bagian tanaman pertanian di atas tanah atau bagian pucuk, batang yang tersisa setelah dipanen atau diambil hasil utamanya. Sriyani (2012) mengklasifikasikan limbah pertanian menjadi limbah prapanen, saat panen, dan pascapanen. Limbah pascapanen terbagi menjadi dua, yaitu limbah sebelum diolah dan limbah setelah diolah atau sering dikenal dengan limbah industri pertanian. Masih terdapat perbedaan dalam penggunaan istilah limbah. Sebagian pelaku usaha di lapangan menyebutkan limbah seperti yang didefinisikan di atas sebagai produk samping. Dikatakan sebagai produk samping karena produk ikutan tersebut masih dapat dimanfaatkan dan memiliki nilai jual. Pada tulisan ini digunakan istilah produk samping karena bahan yang dimaksud adalah bahan yang dapat digunakan untuk pakan ternak dan bernilai jual atau dapat menggantikan produk yang bernilai jual. Berdasarkan jenis tanamannya, produk samping tanaman dan industri pertanian dapat berasal dari tanaman pangan, tanaman hortikultura, dan tanaman perkebunan. Dengan menggunakan teknologi pakan lengkap (complete feed), berbagai produk samping tersebut dapat dijadikan bahan baku untuk menghasilkan pakan dengan harga murah sebagai alternative feeding strategy untuk dapat diaplikasikan secara meluas di berbagai kondisi zona agro ekosistem (Wahyono dan Hardianto, 2004). Pengabdian masyarakat yang dilakukan di Waringin Center dilatar belakangin anggota Waringin center adalah peternak domba dan kambing. Diharapkan pengenalan Hijaun Pakan Ternak (HPT) secara luas berperan besar dalam peningkatan produktivitas ruminansia, yang sangat mendukung upaya tercapainya swasembada daging secara nasional. Selain pengenalan Hijauan Pakan Ternak dikenalkan juga hasil samping pertanian dan industri pertanian yang dapat dimanfaatkan peternak sebagai bahan pakan atau pakan ternak ruminansia.

\section{METODE}

Kegiatan pengabdian Masyarakat ini dilakukan di Waringin Center Stabat Langkat. Peserta pelatihan adalah anggota peternak Waringin Center. Ternak yang dipelihara anggota Waringin Center adalah ruminansia kecil yaitu kambing dan domba. Metode pelaksanaan Kegiatan Pengabdian Masyarakat yang dilakukan adalah dengan 3 tahap. Adapun uraian kegiatan tersebut yaitu: 


\section{Survey}

Tim PKM Dosen Fakultas Pertanian dan Peternakan Universitas Tjut Nyak Dhien beserta beberapa mahasiswa adalah mensurvei kandang anggota Waringin Center dan kandang Waringin Center untuk mengetahui cara pemberian pakan ternak. Setalah dilakukan survey kemudian mengumpulkan anggota Waringin Center untuk mengikuti pelatihan

\section{Ceramah}

Kegiatan ceramah dilakukan dengan 3 sesim sesi 1 dan 2 diisi dari 2 orang Dosen Fakultas Pertanian dan Peternakan yang menjelaskan tentang pengenalan hijauan pakan ternak serta hasil samping pertanian yang dapat dimanfaatkan sebagai pakan ternak. Sesi ke 3 diisi oleh Ketua Waringin Center yang menjelaskan mengenai kondisi peternakan Waringin center dan peternakan Anggota Waringin center serta menjelaskan kelebihan dan kelemahan mereka dalam mengelola peternakan ruminansia kecil terutama dalam memenuhi kebutuhan pakan ternak.

\section{Tanya Jawab (Diskusi)}

Pada sesi Tanya Jawab ini para anggota peternak diberi waktu dan kesempatan untuk memberikan pendapat,pengalaman, dan pertanyaan, serta penyampaian kendala yang sering dihadapi dalam memenuhi kebutuhan pakan ternak.

Dari hasil diskusi yang diperoleh adalah para peserta sangat antusias dalam melakukan diskusi dilihat dari banyaknya peserta yang memberikan tanggapan dan pengalaman serta harapan kedepannya yang dapat mereka lakukan untuk meningkatkan produksi tenak ruminansia kecil terutama dalam pengenalan hijauan pakan ternak dan pemanfaatan hasil samping disekitar mereka yang aman untuk dijadikan pakan ternak.

\section{HASIL DAN PEMBAHASAN}

\section{Survey}

Survey dilakukan oleh tim PKM yaitu Dosen Fakultas Pertanian dan Peternakan Universitas Tjut Nyak Dhien Medan dibantu oleh 5 mahasiswa. Survey yang dilakukan pertama adalah ke Waringin Center Stabat Langkat dan melihat kondisi peternakan di tempat tersebut dapat dilihat pada Gambar 1.

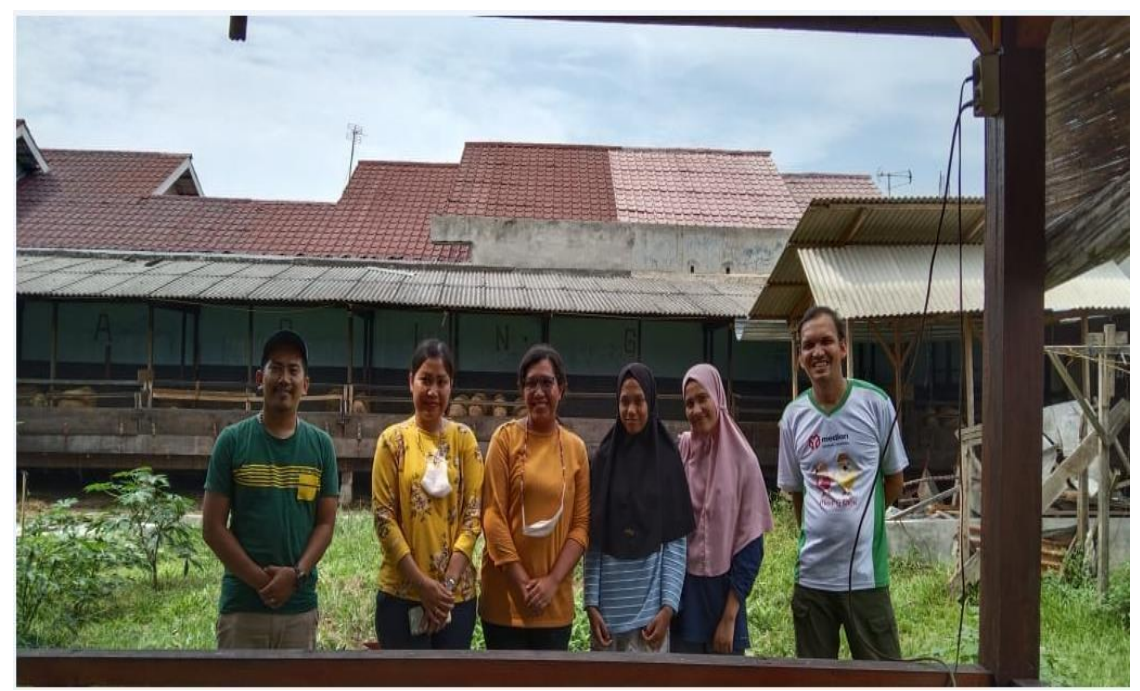

Gambar 1. Survey tempat Waringin Center Stabat Langkat

Melalui Waringin Center didapat informasi anggota kelompok peternak Waringin Center untuk dapat meninjau kekandang-kandang peternak anggota mereka. Survey dilakukan untuk melihat bagaimana cara pemberian pakan, jenis pakan yang diberikan pada peternakan anggota Waringin Center. Survey dilakukan dengan wawancara kepada peternak kemudian hasil wawancara dijadikan sebagai tambahan informasi untuk melakukan kegiatan diskusi dengan peternak. 


\section{Ceramah}

Ceramah yang dilakukan adalah dibagi 3 pemateri. Pemaparan Materi Pengenalan Hijauan Pakan ternak di Waringin Center dilakukan oleh Ibu Juli Mutiara Sihombing, SPt,MPt. Beliau mengutarakan tentang kepedulian perguruan tinggi Fakultas Pertanian dan Peternakan Universitas Tjut

Nyak Dhien terhadap peternak ruminansia yang terus berusaha dalam meningkatkan produktivitas ternaknya. Beliau juga menjelaskan tentang pentingnya pengenalan hiajuan pakan ternak sehingga peternak dapat mengelola pakan dengan baik termasuk hijuan pakan yang ada disekitar daerah tempat tinggal peternak atau dapat dilakukan penanaman hijauan tanpa mengurangi lahan penanaman pertanian. Secara umum sumber bahan pakan untuk ternak dibagi menjadi 2 yaitu hijauan dan non hijauan. Berdasarkan asalnya, sumber hijauan banyak didapatkan dari jenis rumput, legum dan daun- daunan sedangkan sumber non hijauan banyak didapatkan dari biji-bijian dan bahan sumber mineral. Secara pengadaannya, hijauan dapat disediakan secara alami ataupun buatan (dengan budidaya). Untuk pengadaan secara alami biasanya sudah tersedia di alam atau tumbuh dengan sendirinya di lahan-lahan tertentu seperti perkebunan, pertanian dan kehutanan. Sedangkan pengadaan secara budidaya harus melalui penanaman dan pemeliharaan secara intensif. Beliau juga menjelaskan jenis- jenis hijuauan pakan ternak baik ciri-ciri tanaman maupun produksinya. Beliau juga menjelaskan jenis hijauan yang ada disekitar perternak serta yang dapat ditanaman dan dikelola serta dijelaskan juga bagaimana cara pemberian hijauan yang baik ke ternak.

Pemaparan Materi Pemanfatan Hasil Samping Pertanian sebagai pakan ternak dilakukan oleh Ibu Ir. Yunida Berliana, MP. Beliau menjelaskan bahwa Hasil Samping Pertanian dapat dimanfaatkan sebagai pakan ternak. Selama ini hasil samping pertanian dianggap sebagai limbah yang dibuang begitu saja, maka dengan adanya pemanfaatan hasil samping tersebut dapat diolah sebagai pakan ternak yang membantu peternak dalam mencukupi kebutuhan pakan ternak sehingga tercukupi nutrisi ternak dalam menghasilkan produktivitas yang lebih baik. Beliau juga menjelaskan apa saja hasil samping pertanian yang dapat dimanfaatkan sebagai pakan ternak serta bagai mana cara pemberiannya keternak. Sehingga dengan Pengelolaan dan cara pemberian yang tepat akan menunjukkan hasil dari libah pertanian sebagai pakan ternak. Pemateri yang ketiga adalah ketua Waringin Center

Bapak M. Mirsal Tisna Aulia, ST yang memaparkan kendala-kendala yang dihadapi peternak Waringin Center untuk meningkatkan produksi ternak ruminansia kecil terutama dalam penyediaan kebutuhan hijauan pakan ternak.

\section{Tanya Jawab (Diskusi)}

Pada sesi Tanya jawab peserta diberikan waktu untuk member tanggapan dan pendapat dari materi yang dipaparkan pemateri dan juga mengajukan pertanyaan. Pada saat diskusi peternak juga menyampaikan keluhan mereka saat mendapatkan dan memberikan hijuan karena pengetahuan mereka masih belum maksimal dalam pengenalan hijauan pakan dan mereka menanyakan bagaimana solusi terbaik dalam pemberian dan pemanfaatn hasil samping pertanian yang ada disekitar mereka.
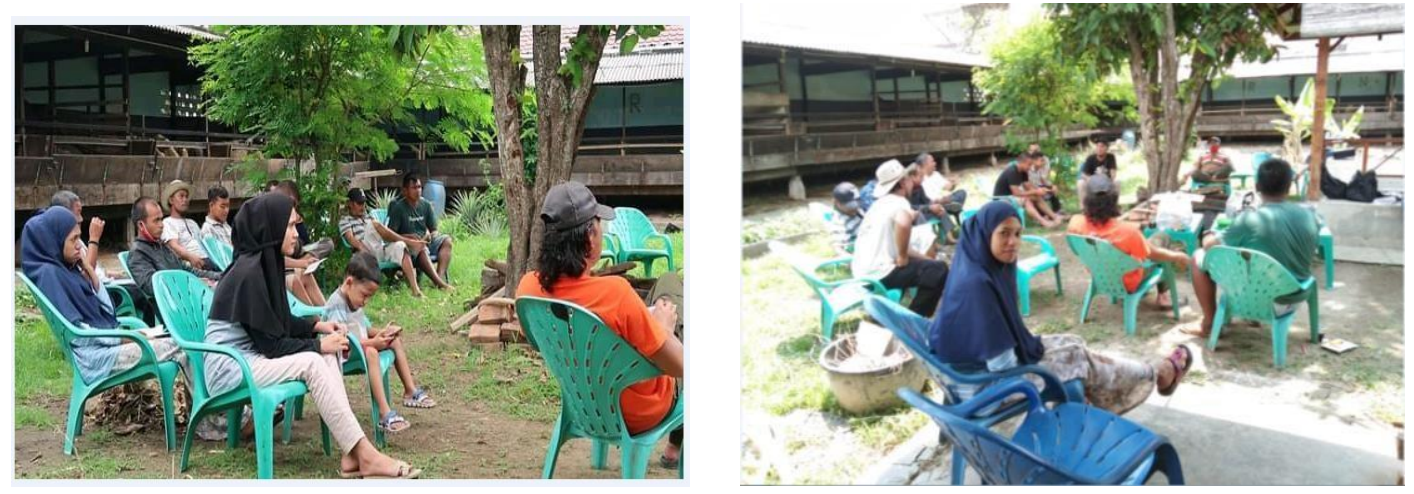

Gambar 2. Kegiatan pemaparan dan diskusi yang diikuti peserta 


\section{KESIMPULAN}

Pengabdian dilakukan dan berjalan lancar dan peserta kegiatan dapat memahami dan mengetahui jenis-jenis hijauan pakan dan hasil samping pertanian yang dapat dimanfaatkan sebagai pekan ternak sehingga dapat meningkatkan produkstivitas ternak ruminansia kecil yang dimiliki peternak. Diharapkan dari kegitan ini dapat meningkatkan pengetahuan dan semangat peternak untuk meningkatkan hasil ternaknya

\section{DAFTAR RUJUKAN}

1. Mulyono,S. 1998. Tenik pembibitan Kambing dan Domba. Penebar Swadaya, Jakarta

2. Sugeng, B. Y. 2000. Beternak Domba. Penebar swadaya. Jakarta.

3. Sutrisno, C. I. 2002. Peran Teknologi Pengolahan Limbah Pertanian dalam Pengembangan Ternak Ruminansia. Semarang: Universitas Diponegoro.

4. Sriyani, F. 2012. Pengertian limbah pertanian. Beranda. http://Spoilerin.blogspot.com/2012/ 03/pengertian-limbah-pertanian.html. (20 Januari 2015).

5. Wahyono, D.E. dan R. Hardianto. 2004. Pemanfaatan sumberdaya pakan lokal untuk pengembangan usaha sapi potong. Prosiding Lokakarya Nasional Sapi Potong Tahun 2004. Bogor: Pusat Penelitian dan Pengembangan Peternakan

6. Williamson, G dan W.J.A Payne. 1993. An Introduction Husbandry In The Tropic. Longman Group london. Terjemahan Darmadja. D. SGN. 1993. Pengantar Peternakan di Daerah Tropis. Gadjah Mada University Press. Yogyakarta.

7. Wodzicka-Tomaszewska, I. M Mashka, A. Djajanegara, S. Gardiner dan T. P. Wiradaya. 1993.

8. Produksi Kambing dan Domba di Indonesia. Sebelas Maret University Press. Surakarta. 